\title{
Pneumonectomy - permanent injury or still effective method of treatment? Early and long-term results and quality of life after pneumonectomy due to non-small cell lung cancer
}

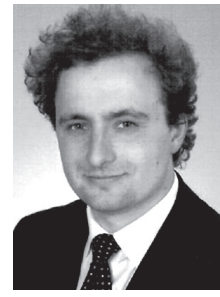

Piotr J. Skrzypczak ${ }^{1}$, Magdalena Roszak ${ }^{2}$, Mariusz Kasprzyk ${ }^{1}$, Anna Kopczyńska ${ }^{3}$, Piotr Gabryel ${ }^{1}$, Wojciech Dyszkiewicz ${ }^{1}$

${ }^{1}$ Department of Thoracic Surgery, Wielkopolska Centre for Pulmonology and Thoracic Surgery, Poznan University of Medical Sciences, Poznan, Poland

${ }^{2}$ Department of Computer Science and Statistics, Poznan University of Medical Sciences, Poznan, Poland

${ }^{3}$ Department of Oncology, University Hospital of Lord's Transfiguration, Poznan University of Medical Sciences, Poznan, Poland

Kardiochirurgia i Torakochirurgia Polska 2019; 16 (1): 7-12

\begin{abstract}
Introduction: Despite the constant decrease of performed pneumonectomies (PN) in recent years, it is still necessary for $15-20 \%$ of patients with non-small cell lung cancer (NSCLC) to undergo total lung resection due to the local progression of the disease.

Aim: To assess the frequency and type of postoperative complications, quality of life, and the early and long-term results after PN performed due to NSCLC.

Material and methods: In the total group of 1160 patients, operated on in 2008-2011 due to NSCLC, 192 of them underwent PN (16.6\%). The quality of life was analysed using EORTCQLQ-C30 questionnaire.

Results: Perioperative mortality after PN was 4\%. Five-year survival reached $45 \%$. The factors that significantly affected the 5-year survival in multivariate analysis were: pTNM stage, pN stage, intrapericardial resection, and additional extrapulmonary structures resection. The mean Global Quality of Life was 50.8. The Symptom Scale ranged from 7 to 54.3, the Functional Scale from 58.2 to 76.3 and the rate for NSCLC symptoms ranged from 2.2 to 48.1 .

Conclusions: Pneumonectomies in patients with NSCLC is associated with higher risk of postoperative complications but it does not significantly increase the perioperative mortality. Long-term results in this group of patients are encouraging. According to the questionnaire, the quality of life is favourable. Low intensity of typical NSCLC symptoms was observed. The appropriate qualification for right-sided PN and exclusion of metastasis in N2 nodes are crucial.
\end{abstract}

Key words: pneumonectomy, non-small cell lung cancer, quality of life, EORTC-QLQ-C30.

\section{Streszczenie}

Wprowadzenie: Pomimo że ogólna liczba wykonywanych rocznie pneumonektomii (PN) systematycznie zmniejsza się w ostatnich latach, całkowita resekcja płuca jest wciąż jednym z preferowanych zabiegów u 15-20\% pacjentów z miejscowo zaawansowanym niedrobnokomórkowym rakiem płuca (NSCLC).

Cel: Ocena częstości i typu powikłań pooperacyjnych, jakości życia oraz wczesnych i odległych wyników u pacjentów po PN wykonanej z powodu NSCLC.

Materiat i metody: Spośród 1160 pacjentów operowanych w latach 2008-2011 z powodu NSCLC u 192 (16,6\%) wykonano PN. Jakość życia analizowano przy użyciu ankiety EORTC-QLQ-C30. Wyniki: Śmiertelność okołooperacyjna wyniosła 4\%. Przeżycie 5-letnie osiągnęło 45\%. Czynnikami, które w analizie wieloczynnikowej istotnie wpływały na 5-letnie przeżycie, były: stopień pTNM, stopień pN, resekcja wewnątrzosierdziowa oraz dodatkowa resekcja struktur pozapłucnych. Średnia wartość Global Quality of Life wyniosła 50,8. Wartości Symptom Scale mieściły się w granicach 7-54,3, Functional Scale 58,2-76,3, natomiast wartości skali oceniającej częstość zwykle stwierdzanych objawów NSCLC wyniosły 2,2-48,1.

Wnioski: Pneumonektomia wykonywana u pacjentów z NSCLC wiąże się z większym ryzykiem wystąpienia powikłań pooperacyjnych, ale nie zwiększa istotnie statystycznie śmiertelności okołooperacyjnej. Wyniki odległe w tej grupie pacjentów są zachęcające. Na podstawie ankiet stwierdzono, że jakość życia po zabiegu jest satysfakcjonująca. Zaobserwowano również niską częstość występowania objawów typowych dla NSCLC. Istotne są właściwa kwalifikacja do prawostronnej PN oraz wykluczenie przerzutów w węzłach N2.

Słowa kluczowe: pneumonektomia, niedrobnokomórkowy rak płuca, jakość życia, EORTC-QLQ-C30.

Address for correspondence: Piotr J. Skrzypczak MD, PhD, Department of Thoracic Surgery, Wielkopolska Centre for Pulmonology and Thoracic Surgery, Poznan University of Medical Sciences, Poznan, Poland, e-mail: piotr.j.skrzypczak@gmail.com Received: 29.12.2018, accepted: 31.01.2019. 


\section{Introduction}

Since the time of performing the first pneumonectomy (PN) in 1933, the number of total lung resections constantly decreases. Increasingly PN is being replaced by more parenchyma-sparing techniques like sleeve-lobectomy (SL) [1-3].

Pneumonectomy is associated with both higher mortality and postoperative complication rates compared to SL [1]. Also, the indications for PN have been decreasing for several years [2]. Despite the lower number of PNs, which has been observed in recent years, it is still necessary for $15-20 \%$ of patients with non-small cell lung cancer (NSCLC) to undergo total lung resection due to local malignancy of the disease [3]. Pneumonectomy is generally indicated for malignant tumours, infections or degenerative lesions, that cannot be treated with more parenchyma-sparing resections [4]. Despite the larger perioperative trauma and higher mortality rate [5], both elements - operative technique and the postoperative care - have improved and favourable outcomes of 5-year survival and quality of life (QoL) are achievable [3]. Very important for each patient who is going to undergo PN is the expected QoL and possible consequences of the operation [4-8]. The higher operation quality and improved postoperative care lead to higher expectations regarding the daily activity after the operation [9]. The role of the doctor should be not only choosing the most effective and radical method of treatment but also explaining to the patient the consequences of that choice, engaging the patient in the treatment process. That is why patients should be obligatorily informed about the impact of the total lung resection on the QoL in the preoperative period [10].

\section{Aim}

The aim of the study was to assess the type and the frequency of postoperative complications, the long-term results, and the QoL after PN in NSCLC patients.

\section{Material and methods}

In the total group of 1160 patients, operated on in 20082011 due to NSCLC, 192 patients underwent PN (16.6\%). There were 44 women and 148 men in the analysed group, in the age range of 32-79 years (mean: 60). Diagnostic imaging (CT scan, PET/CT), endoscopy (bronchofibroscopy, autofluorescence bronchoscopy, EBUS-TBNA), and the other examination procedures ("blind" transbronchial biopsy, transthoracic needle aspiration biopsy) were performed during the diagnostic process and qualification for PN. The patients with locally operative tumours (evaluation based on CT scan and bronchofibroscopy), excluded from distant metastases (PET/CT, abdominal and brain CT, brain NMR and bone scintigraphy) and mediastinal lymph nodes metastases (PET/CT, EBUS, mediastinoscopy), with favourable results of the studies assessing efficiency of respiratory and cardiovascular systems were qualified for PN. In the functional assessment of the respiratory system spirometry, diffusing capacity of the lung for carbon monoxide (DLCO) and capillary blood gas screening were routinely performed. In some patients also a 6-minute walk test and stair test were carried out. In doubtful situations, the predicted postoperative value of the forced expiratory volume in 1 second $\left(\right.$ ppoFEV $_{1}$ ) and predicted postoperative diffusing capacity of the lung for carbon monoxide (ppoDLCO) were calculated. Cardiovascular evaluations were assumed according to electrocardiography (ECG) and echocardiography. Some cases required additional studies (exercise test, Holter monitoring, coronary angiography). Pneumonectomy was performed under general intravenous anaesthesia with bronchial intubation and anterolateral thoracotomy access. In 13\% of cases, the lung hilum vessels were supplied intrapericardially. In 150 (78.1\%) patients the bronchial stump was closed with a manual suture (double layer of the continuous PDS 3-0 suture), in the remaining $42(21.9 \%)$ with the mechanical suture (linear stapler). The bronchial stump was strengthened with tissue flaps (intercostal muscle, pericardium, thymus, pleura or mediastinal fat tissue) in 162 (84.4\%) patients. Each patient underwent complete mediastinal lymphadenectomy.

Obtaining the postoperative histopathological examination result was followed by assessing the stage of the cancer according to the $7^{\text {th }}$ edition of the 2009 TNM classification. Each patient was consulted by an oncologist and the qualification for adjuvant therapy (chemo- and/or radiotherapy) depended on the malignancy of the cancer, the general condition and the presence of accompanying diseases.

Clinical data were obtained using thoracic surgery and oncology departments' medical records. The patients' postoperative follow-up was based on the information from thoracic surgery and oncology clinics and also the questionnaires that were sent to the patients.

\section{Statistical analysis}

Statistical calculations were performed using Statistica 12.0 PL software (StatSoft Polska, Kraków, Poland) or StatXact 9.0 (Cytel Inc., Cambridge, MA, USA). Categorical data were analysed with the $\chi^{2}$ test or the Fisher-Freeman-Halton test. All results were considered significant at $p<0.05$. Analysed data are presented as means and standard deviations, medians and interquartile ranges or absolute numbers and/or percentages, as appropriate. The unpaired t-test was used to analyse the data with normal distribution and homogeneous variances. Normality of the distribution was tested with the Shapiro-Wilk test, and the equality of variances was checked with Levene's test. The data that did not follow a Gaussian distribution were analysed with the Mann-Whitney $U$ test. The relationship between variables was analysed with Spearman's rank correlation coefficient and by multiple logistic regression. For overall survival we used the Kaplan-Meier method in a univariate analysis, and differences between subgroups were assessed by the log-rank test.

The QoL was analysed using version 3.0 of the European Organization for Research and Treatment of Cancer Quality of Life Questionnaire C30 (EORTC QLQ-C30) and the EORTC QLQ-LC13 module. The results have been calculated and 
compared with the EORTC's reference values for the general population and for all cancer patients [11]. After receiving the permission from EORTC to use the questionnaires, they were sent to the patients in April 2015 and collected from May to July 2015. The EORTC QLQ-C30 is a standardized and complex instrument for examining the symptoms of cancer or the patient's general condition and functioning during treatment. The EORTC QLQ-C30 consists of questions that are divided into three scales: the Symptoms Scale, the Global Health Status (QoL) and the Functional Scale. The possible degrees of assessment for the items were "not at all", "a little", "quite a bit", and "very much" with the exception of the two questions that evaluate the Global QoL ranging from (1) "very poor" to (7) "excellent". Cronbach's $\alpha$ of the Global QoL scale was 0.94. A high score on the Symptom Scale (Cronbach's $\alpha=0.83$ ) represents a high level of symptomatology. A high Global Health Status (Cronbach's $\alpha=0.94$ ) and Functional Scale (Cronbach's $\alpha=0.89$ ) represent a high QoL and high level of functioning. The questionnaire also includes a specific LC13 supplement, which includes 13 questions and incorporates one multi-item scale to assess typical lung cancer symptoms such as coughing, dyspnoea, haemoptysis and pain in the chest [11]. The questionnaire response rate was $72 \%$.

\section{Results}

Among 192 operated patients in 83 right PN and in 109 left PN were performed. The most common histological type of the tumour was squamous cell carcinoma (71.4\%). Adenocarcinoma was diagnosed in $20.3 \%$. For 139 (72.4\%) patients the most common comorbidities were: hypertension (33.9\%), chronic obstructive pulmonary disease (23.4\%), ischaemic heart disease (12\%), diabetes (9.9\%), history of myocardial infarction (8.9\%) and arrhythmia (4.7\%). 16.1\% of patients were operated on in stage I, $47.4 \%$ in stage II, and $35.4 \%$ in stage III. Metastases in lymph nodes N1 were observed in the group of $87(45.3 \%)$ patients and in $49(25.5 \%)$ the N2 stage was confirmed. $52.7 \%$ of patients were treated with chemo-and/or radiotherapy. Thirteen patients underwent preoperative chemotherapy with a satisfactory response to treatment. Table I shows the clinical and pathological data in the analysed group of patients. The mortality rate during hospitalization was $4.2 \%$ and was higher after right-sided PN (4.8\% vs. 3.7\%). A number of factors that could potentially have influence the postoperative mortality rate (age, gender, TNM staging, preoperative $\mathrm{FEV}_{1}$, preoperative FVC, operated side, resection of additional structures, intrapericardial resection, bronchopleural fistula, postoperative bleeding, other complications, blood transfusion, comorbidities, preoperative chemotherapy) were statistically analysed. The only factor that significantly affected the mortality rate was a history of myocardial infarction. Postoperative mortality in this group was $17.6 \%$ and among the other patients $2.9 \%(p=0.02)$.

The time of the hospitalization was 5-98 days (mean: 17). The time spent in the Intensive Care Unit was 0-66 days (mean: 6).
Table I. Study group patients' clinical characteristics

\begin{tabular}{|c|c|}
\hline Parameter & Value \\
\hline Age [years] & 32-79 (mean: 60) \\
\hline $\begin{array}{l}\text { Gender: } \\
\text { Male/female, } n(\%)\end{array}$ & $148(77.1) / 44(22.9)$ \\
\hline $\begin{array}{l}\text { Comorbidities, } n(\%): \\
\text { Hypertension } \\
\text { COPD } \\
\text { Ischaemic heart disease } \\
\text { Diabetes } \\
\text { History of myocardial infarction } \\
\text { Arrhythmia }\end{array}$ & $\begin{array}{c}139(72.4) \\
65(33.9) \\
45(23.4) \\
23(12) \\
19(9.9) \\
17(8.9) \\
9(4.7) \\
\end{array}$ \\
\hline $\begin{array}{l}\text { Spirometry: } \\
\mathrm{FEV}_{1}, \% \text { (mean) } \\
\mathrm{FVC} \\
\mathrm{FEV}_{1} \% \mathrm{FVC} \\
\end{array}$ & $\begin{array}{c}45.4-121(78.8) \\
46.9-128.4(87.1) \\
57.3-122(92.9) \\
\end{array}$ \\
\hline $\begin{array}{l}\text { Histology, } n \text { (\%): } \\
\text { Squamous cell carcinoma } \\
\text { Adenocarcinoma } \\
\text { Large cell carcinoma } \\
\text { Others }\end{array}$ & $\begin{array}{c}137(71.4) \\
39(20.3) \\
9(4.7) \\
7(3.7) \\
\end{array}$ \\
\hline $\begin{array}{l}\text { Grading, } n(\%): \\
\text { G1 } \\
\text { G2 } \\
\text { G3 } \\
\text { Gx }\end{array}$ & $\begin{array}{l}12(6.3) \\
119(62) \\
41(21.4) \\
20(10.4)\end{array}$ \\
\hline $\begin{array}{l}\text { pN stage, } n(\%) \text { : } \\
\text { N0 } \\
\text { N1 } \\
\text { N2 }\end{array}$ & $\begin{array}{l}56(29.2) \\
87(45.3) \\
49(25.5)\end{array}$ \\
\hline $\begin{array}{l}\text { Pathological staging, } n \text { (\%): } \\
\text { II } \\
\text { III }\end{array}$ & $\begin{array}{l}31(16.1) \\
91(47.4) \\
68(35.4) \\
2(1.1)\end{array}$ \\
\hline $\begin{array}{l}\text { Side of procedure (pneumonectomy), } n(\%) \text { : } \\
\text { Right } \\
\text { Left }\end{array}$ & $\begin{array}{c}83(43.2) \\
109(56.8)\end{array}$ \\
\hline Intrapericardial resection, $n(\%)$ & $25(13)$ \\
\hline Resection of additional structures, $n$ (\%) & $29(15.1)$ \\
\hline $\begin{array}{l}\text { Technique of bronchial stump closure, } n \text { (\%): } \\
\text { Manual suture } \\
\text { Stapler } \\
\text { Coverage using a flap of viable tissue }\end{array}$ & $\begin{array}{l}150(78.1) \\
42(21.9) \\
162(84.4)\end{array}$ \\
\hline $\begin{array}{l}\text { Oncological therapy, } n(\%): \\
\text { Neoadjuvant chemotherapy } \\
\text { Postoperative chemotherapy } \\
\text { Postoperative radiotherapy }\end{array}$ & $\begin{array}{l}13(6.8) \\
66(34.4) \\
22(11.5)\end{array}$ \\
\hline
\end{tabular}

Postoperative complications occurred in 109 (56.7\%) patients. The most common were as follows: atrial fibrillation (31.8\%), anaemia requiring transfusion (29.7\%), renal failure (19.3\%), bleeding requiring reoperation (6.8\%), psychosis (5.7\%). In $8.9 \%$ of cases, bronchopleural fistula was found, more often on the right side ( $14.5 \%$ vs. $4.8 \%$, $p<0.05)$. The occurrence of bronchopleural fistula or other complications did not significantly affect postoperative mortality or long-term survival. Table II shows the rate of selected postoperative complications.

The percentage of 5-year survival in the entire population was $44.8 \%$. Overall 5-year survival rates for individual 
Table II. Postoperative complications frequency

\begin{tabular}{lc} 
Complications & Value \\
Postoperative mortality, $n$ (\%): & \\
Total & $8(4.2)$ \\
Right pneumonectomy & $4(4.8)$ \\
Left pneumonectomy & $4(3.7)$ \\
\hline Incidence of complications, $n$ (\%): & \\
Total & $109(56.7)$ \\
Right pneumonectomy & $44(53)$ \\
Left pneumonectomy & $65(59.6)$ \\
\hline The most common complications, $n$ (\%): & \\
Atrial fibrillation & $61(31.8)$ \\
Anaemia requiring transfusion & $57(29.7)$ \\
Renal failure & $37(19.3)$ \\
Broncho-pleural fistula & $17(8.9)$ \\
Bleeding requiring reoperation & $13(6.8)$ \\
Psychosis & $11(5.7)$ \\
Empyema without broncho-pleural fistula & $4(2.1)$ \\
Cerebral ischaemia & $5(2.6)$ \\
\hline Hospital stay (mean) [days] & $5-98(17)$ \\
\hline ICU stay (mean) [days] & $0-66(6)$ \\
\hline
\end{tabular}

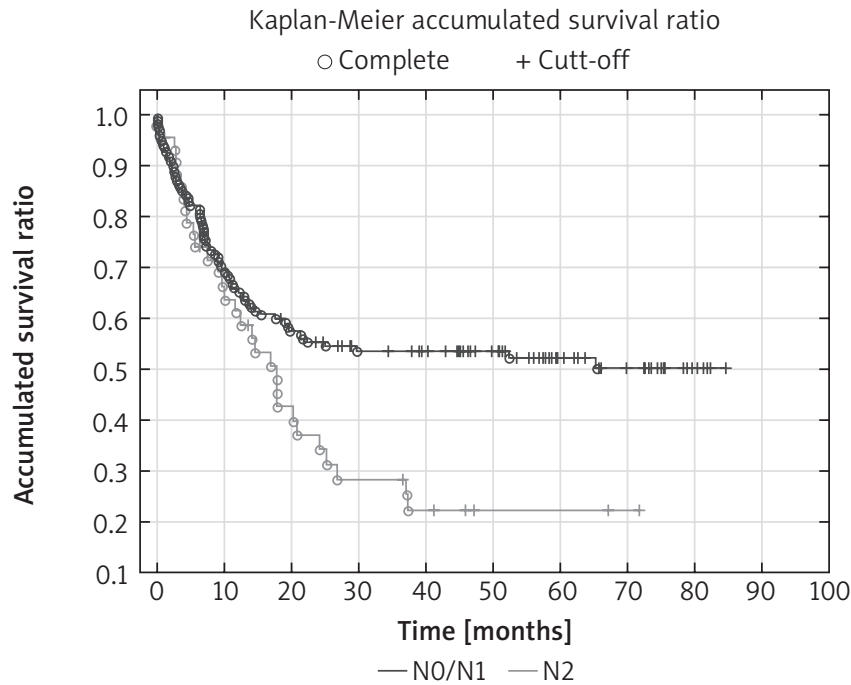

Fig. 2. Overall survival curves according to $\mathrm{pN}$ stage: KaplanMeier accumulated survival ratio reveals significant difference $(p<0.05)$ between time survived rate in patients with NO/N1 or N2 $(p=0.013)$

Table III. Survival univariate and multivariate analysis

\begin{tabular}{lc} 
Variable & P-value \\
Univariate analysis: & \\
T stage & 0.03 \\
N stage & 0.04 \\
Pathological stage (TNM) & 0.03 \\
Resection of additional structures & 0.01 \\
Intrapericardial resection & 0.03 \\
Adjuvant chemotherapy & 0.003 \\
\hline Multivariate analysis: & \\
Pathological stage (TNM) & 0.00009 \\
N stage & 0.0002 \\
Resection of additional structures & 0.04 \\
Intrapericardial resection & 0.01 \\
\hline
\end{tabular}

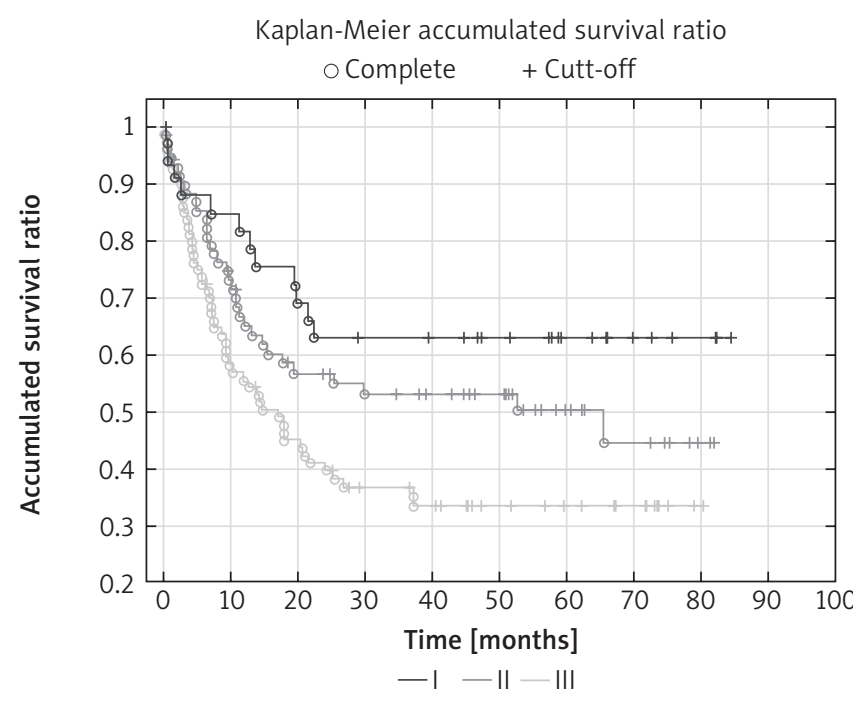

Fig. 1. Overall survival curves according to pTNM stage: KaplanMeier accumulated survival ratio reveals significant difference $(p<0.05)$ between time survived rate in patients with PTNM I, II or III $(p=0.017)$

TNM stages of cancer were: I - 62\%, II - 50\%, III - 33\% ( $p<0.05$ ). $63.3 \%$ of N2 patients, $35.6 \%$ of patients with N1 and $26.8 \%$ of NO patients died in the observation period $(p<0.05)$. The factors that significantly influenced the longterm results in univariate analysis were: $\mathrm{pT}$ stage, $\mathrm{pN}$ stage, pTNM stage, intrapericardial resection, resection of extrapulmonary structures and postoperative chemotherapy. In multivariate analysis, four features significantly affected the 5-year survival: pTNM stage (Fig. 1), pN stage (Fig. 2), intrapericardial resection and resection of additional extrapulmonary structures (Table III).

The risk of death after additional resection was more than 6 times higher compared with those without resection of extrapulmonary structures $(O R=6.4)$. The intrapericardial resection increased the risk of death twofold $(O R=2.8)$. The risk of death in the absence of adjuvant chemotherapy was more than 2 times higher compared to those who had adjuvant chemotherapy $(O R=2.5)$. There was a relationship between the $\mathrm{N}$ stage and the survival rate. The number of deaths in the N0/N1 group differed significantly (44.2\%) from the number of deaths in the N2 group (68.2\%).

The EORTC QLQ- LC13 questionnaire consisted of 43 questions, which patients were able to answer by choosing the numerical value to describe the intensity of a given object. The EORTC QLQ-LC13 questionnaire consisted of questions that were divided into four categories: Symptoms Scale, Functional Scale, Global QoL and the EORTC LC13 supplement, which is the 13-item lung cancer-specific questionnaire module. The results were compared to the EORTC QLQ-LC13 References Values. Only 3\% of patients rated their general condition and QoL as "very bad". Seventy-four percent rated this category from "medium" to "excellent" (4 to 7 points, 50,8). The pain rate was 32.8. Also, $22.6 \%$ of patients did not have any pain or the pain did not disturb their daily activity. The most common and intensive symptom that patients were suffering from was dyspnoea 
(48.1-54.3). Over $16 \%$ of patients rated these symptoms as "very often" (4 points). Many patients presented high cognitive functioning (76.3\%). The physical functioning was presented as follows: $3-8 \%$ of patients have very often difficulties with a short walk or they have to rest in bed or on a couch during the day (4 points), $84 \%$ of patients do not need any help with eating, dressing, washing or using the toilet (1 point) (Table IV).

\section{Discussion}

In the last few decades, the number of PNs performed in patients with NSCLC has been systematically decreasing and currently in most thoracic surgery departments does not exceed $15 \%$ of the total anatomical resections $[1,12]$. The decreasing number of the PNs is associated with, on the one hand, the higher number of detected cases of early-stage lung cancer with low-dose CT scans, and on the other hand by the increasingly frequent performance of lung resection using parenchyma-sparing procedures such as SL. Indications for both PN and SL are centrally located tumours, invading the main bronchial or vascular structures of the hilum of the lung. Many authors report favourable early and long-term results of the SLS, highlighting the lower complications rate, the higher 5-year survival rate, and better QoL compared to PN $[12,13]$. However, it is crucial that the $S L$ can be performed only in a relatively small group of patients with favourable anatomical conditions. There is a fairly large population of patients with locally advanced lung cancer, whose only option for radical surgical treatment, and therefore a chance for complete recovery, is the PN. Although the postoperative mortality rate and the frequency of serious complications after resection of the entire lung are higher than after standard lobectomy or $\mathrm{SL}$, the distant outcomes reported by some authors are encouraging. Riquet and co-authors analysed early and longterm results in a group of 1446 patients who underwent PN due to NSCLC. The postoperative mortality rate was $6.3 \%$, complications occurred in $27 \%$ of patients and the 5 - and the 10 -year survival rates were $32 \%$ and $19 \%$ [14]. In other publications, the postoperative complication rate after PN ranges from $22 \%$ to $44 \%[15,16]$. The serious complication rate (life-threatening or requiring reoperation) is about $16 \%$ [1], the occurrence of bronchopleural fistulas ranges from $3.6 \%$ to $16 \%$ [15-17], and postoperative mortality is 3.6\% to $11.2 \%[15,18,19]$. Five-year survival rates in all TNM stages fluctuate between $21 \%$ and $39 \%$ [20, 21]. In the group analysed in this study complications occurred in $56.7 \%$ of patients, the postoperative mortality rate was $4.2 \%$ and the 5 -year survival rate reached $45 \%$. Bronchopleural fistula occurred in $8.9 \%$ of patients and was more frequent on the right side. Similarly to other authors, the TNM staging, especially $\mathrm{N}$-stage, and the extension of the surgery (extended PN) were the determinants of the long-term outcomes. Unlike other reports [14, 22], in our material postoperative complications (including bronchopleural fistula) did not affect postoperative mortality or distant survival. A significant influence of age, gender or comorbidities on
Table IV. Results of the EORTC QLQ-C30 and EORTC QLQ-L13 questionnaires

The questionnaire consists of questions that were divided into four categories: Symptoms Scale, Functional Scale, Global Quality of Life and the EORTC LC13 supplement, which is the 13-item lung cancer-specific questionnaire module. A high score for Symptom Scale represents a high level of symptomatology. A high Global Health Status and Functional Scale represent a high quality of life and high level of functioning. The LC13 supplement assesses the intensity of typical lung cancer symptoms.

\begin{tabular}{lc} 
Variable & $\begin{array}{c}\text { Test-retest reliability } \\
\text { (follow-up group, } n=62 \text { ) }\end{array}$ \\
QLQ-C30: & \\
Physical functioning & 58.2 \\
Role functioning & 65.9 \\
Emotional functioning & 59.5 \\
Cognitive functioning & 76.3 \\
Social functioning & 65.9 \\
Global Quality of Life & 50.8 \\
Pain & 32.8 \\
Nausea and vomiting & 9.1 \\
Fatigue & 51.6 \\
Dyspnoea & 54.3 \\
Insomnia & 41.7 \\
Appetite loss & 20.4 \\
Constipation & 27.4 \\
Diarrhoea & 7 \\
Financial difficulties & 38.8 \\
\hline QLQ-C13: & \\
Dyspnoea & 48.1 \\
Coughing & 36.6 \\
Haemoptysis & 2.2 \\
Sore mouth & 6.6 \\
Dysphagia & 14.5 \\
Peripheral neuropathy & 36.1 \\
Alopecia & 18.6 \\
Pain in chest & 36.6 \\
Pain in arm or shoulder & 37.2 \\
Pain in other parts & 29.8 \\
\hline
\end{tabular}

the survival rate was not observed as well. An interesting observation was the relatively high (21\%) 5-year survival rate in the group of patients with metastatic N2 disease. The N2 feature is certainly one of the most important unfavourable predictors. Although in Riquet's publication $26 \%$ of patients with PN who survived 10 years had in the postoperative material metastases in N2 lymph nodes [14], these are significantly better outcomes than those seen in patients treated conservatively (chemoradiotherapy) [23] Based on the results of recently published cohort studies $[15,17]$ and meta-analyses $[12,18], \mathrm{SL}$ is recommended for patients with centrally located lung cancer as long as it is technically feasible.

Obviously, the PN should be still in the arsenal of surgical procedures performed in patients with NSCLC. Performing it in some clinical situations remains controversial, such as in patients with N2 disease, in patients after induction therapy or in patients with high operation risk [4]. Another problem is the QoL after such extensive surgery. For many patients, the risk of significant worsening of the QoL after surgery is an important argument in choosing the type of therapy. Some of them are willing to accept the higher 
risk of the complications in the postoperative period, but they would not accept the significant deterioration in the distant QoL $[24,25]$. Although the results of QoL studies performed using the standardized questionnaires indicate a significant deterioration in the PN group [3], the QoL is not as dramatic as might be expected after such extensive resection. Some authors claim that QoL after PN is comparable or only slightly deviates from the QoL after the SL [1].

According to our questionnaire's results, the QoL is favourable. Lots of symptoms normally associated with postoperative trauma or cancer grading are not observed after such a long (5-7 years) period after PN. Comparing PN with SL, Balduyck et al. observed significant differences in patients' physical functioning, role functioning, social functioning, cognitive functioning, and shoulder dysfunction, but their study included only one year after the operation [24, 25]. Andersson et al. compared the survival rate and the general QoL in a long period of time (mean: 69 months) and described no statistically significant differences in both objects [1]. The problem of the QoL in patients 5-7 years after PN is not widely described in the literature. It requires research that will compare PN to the more parenchyma-sparing procedures (e.g. SL). Also, the evaluation of the results should be analysed in age-divided groups. Our results suggest that PN patients could lead life at a satisfactory level. Additionally, the survival rate (45\%) allows us to claim that in properly qualified cases, there is still a place for PN as an effective method of treatment of NSCLC.

\section{Conclusions}

Our study confirmed a relatively high risk of postoperative complications in patients undergoing PN for NSCLC but it does not significantly increase perioperative mortality (4\%) and long- term survival. Long-term results in this group of patients are satisfactory and the rate of 5-year survival reaches $45 \%$. According to the questionnaire, the QoL is favourable and it is also higher than could be expected after such extensive resection.

\section{Disclosure}

The authors report no conflict of interest.

\section{References}

1. Andersson SEM, Rauma VHS, Sihvo EI, Räsänen JV, Ilonen IK, Salo JA. Bronchial sleeve resection or pneumonectomy for non-small cell lung cancer: a propensity-matched analysis of long-term results, survival and quality of life. J Thorac Dis 2015; 7: 1742-1748.

2. Martin-Ucar AE, Chaudhuri N, Edwards JG, Waller DA. Can pneumonectomy for non-small cell lung cancer be avoided? An audit of parenchymal sparing lung surgery. Eur J Cardiothorac Surg 2002; 21: 601-605.

3. Ilonen IK, Räsänen JV, Sihvo EI, Knuuttila A, Sovijärvi AR, Sintonen H, Salo JA. Pneumonectomy: post-operative quality of life and lung function. Lung Cancer 2007; 58: 397-402.

4. Janet-Vendroux A, Loi M, Bobbio A, Lococo F, Lupo A, Ledinot P, Magdeleinat $P$, Roche N, Damotte D, Regnard JF, Alifano M. Which is the role of pneumonectomy in the era of parenchymal-sparing procedures? Early/long-term survival and functional results of a single-center experience. Lung 2015; 193: 965-973.
5. Nagasaki F, Flehinger BJ, Martini N. Complications of surgery in the treatment of carcinoma of the lung. Chest 1982; 82: 25-29.

6. Ferguson MK, Vigneswaran WT. Changes in patient presentation and outcomes for major lung resection over three decades. Eur J Cardiothorac Surg 2008; 33: 497-501.

7. Deslauriers J, Ugalde P, Miro S, Deslauriers DR, Ferland S, Bergeron S, Lacasse Y, Provencher S. Long-term physiological consequences of pneumonectomy. Semin Thorac Cardiovasc Surg 2011; 23: 196-202.

8. Suen HC, Hendrix H, Patterson GA. Physiologic consequences of pneumonectomy. Consequences on the esophageal function. Chest Surg Clin N Am 1999; 9: 475-483.

9. Cykert S, Kissling G, Hansen CJ. Patient preferences regarding possible outcomes of lung resection: what outcomes should preoperative evaluations target? Chest 2000; 117: 1551-1559.

10. Kearney DJ, Lee TH, Reilly JJ, Decamp MM, Sugarbaker DJ. Assessment of operative risk in patients undergoing lung resection. Importance of predicted pulmonary function. Chest 1994; 105: 753-759.

11. Scott NW, Fayers PM, Aaronson NK, Bottomley A, De Graeff A, Groenvold M, Gundy C, Koller M, Petersen MA, Sprangers MAG; the EORTC Quality of Life Group EORTC QLQ-C30 reference values. EORTC QLQ-C30 Reference Values 2008.

12. Pagès PB, Mordant $P$, Renaud S, Brouchet L, Thomas PA, Danham M, Bernard $A$. Sleeve lobectomy may provide better outcomes than pneumonectomy for non-small cell lung cancer. A decade in a nationwide study. J Thorac Cardiovasc Surg 2017; 153: 184-195.E3.

13. Stallard J, Loberg A, Dunning J, Dark J. Is a sleeve lobectomy significantly better than a pneumonectomy? Interact Cardiovasc Thorac Surg 2010; 11: 660-666.

14. Riquet M, Mordant P, Pricopi C, Legras A, Foucault C, Dujon A, Arame A, Le Pimpec-Barthes F. A review of 250 ten-year survivors after pneumonectomy for non-small-cell lung cancer. Eur J Cardiothorac Surg 2014; 45: 876-881.

15. Ludwig C, Stoelben E, Olschewski M, Hasse J. Comparison of morbidity, 30-day mortality, and long-term survival after pneumonectomy and sleeve lobectomy for non-small cell lung carcinoma. Ann Thorac Surg 2005; 79: 968-973.

16. Stoelben E, Sauerbrei W, Ludwig C, Hasse J. Tumor stage and early mortality for surgical resections in lung cancer. Langenbecks Arch Surg 2003; 388: 116-121.

17. Bagan P, Le Pimpec-Barthes F, Badia A, Crockett F, Dujon A, Riquet M. Bronchial sleeve resections: lung function resurrecting procedure. Eur J Cardiothorac Surg 2008; 34: 484-487.

18. Ma Z, Dong A, Fan J, Cheng H. Does sleeve lobectomy concomitant with or without pulmonary artery reconstruction (double sleeve) have favorable results for non-small cell lung cancer compared with pneumonectomy? A meta-analysis. Eur J Cardiothorac Surg 2007; 32: 20-28.

19. Kim DJ, Lee JG, Lee CY, Park IK, Chung KY. Long-term survival following pneumonectomy for non-small cell lung cancer: clinical implications for followup care. Chest 2007; 132: 178-184.

20. Ramnath N, Demmy TL, Antun A, Natarajan N, Nwogu CE, Loewen GM, Reid ME. Pneumonectomy for bronchogenic carcinoma: analysis of factors predicting survival. Ann Thorac Surg 2007; 83: 1831-1836.

21. Spaks A, Kopeika U, Pirtnieks A, Basko J, Ambalovs G, Grusina-Ujumaza J, Tracums I, Taivans I. Long-term survival after lobectomy and pneumonectomy in patients with stage II non-small cell lung cancer (NSCLC). Lung Cancer 2012; 77: S39.

22. Fernandez FG, Force SD, Pickens A, Kilgo PD, Luu T, Miller DL. Impact of laterality on early and late survival after pneumonectomy. Ann Thorac Surg 2011; 92: 244-249.

23. Albain K, Swann RS, Rusch VW, Turrisi AT $3^{\text {rd }}$, Shepherd FA, Smith C, Chen Y, Livingston RB, Feins RH, Gandara DR, Fry WA, Darling G, Johnson DH, Green MR, Miller RC, Ley J, Sause WT, Cox JD. Radiotherapy plus chemotherapy with or without surgical resection for stage III non-smallcell lung cancer: a phase III randomised controlled trial. Lancet 2009; 374: 379-386.

24. Balduyck B, Hendriks J, Lauwers P, Van Schil P. Quality of life after lung cancer surgery: a prospective pilot study comparing bronchial sleeve lobectomy with pneumonectomy. J Thorac Oncol 2008; 3: 604-608.

25. Balduyck B, Hendriks J, Lauwers P, Sardari Nia P, Van Schil P. Quality of life evolution after lung cancer surgery in septuagenarians: a prospective study. Eur J Cardiothorac Surg 2009; 35: 1070-1075. 